\title{
DAIANA GÂRDAN
}

\section{REȚETA ROMANULUI REALIST-SOCIALIST. UN EXPERIMENT STILOMETRIC ${ }^{*}$}

Există o estetică a romanului realist-socialist dezvoltată organic, în afara „rețetei”, în România? Există un proces de tip trial and error, similar literaturii de dinaintea instaurării regimului comunist, în cazul acestei literaturi? În România, discursul oficial al epocii vorbește despre o literatură creată de mase, pentru mase, responsabilă pentru educarea în spirit comunist a populației și pentru denunțarea „burgheziei reacționare”, a „exploatatorilor”, a „dușmanilor” (Selejan 2007). Responsabilitatea acestui act creator se extinde și asupra criticii literare, reconvertite peste noapte într-o instanță deopotrivă de promovare a rețetei realist-socialiste și de sancționare a celor care își asumau licențe artistice care contraveneau ideologiei dominante (Goldiş 2011). La finalul anilor 1940, romanul românesc și instituțiile care se ocupă de el iau o turnură nouă, subordonată Partidului Comunist, care părăsește orice pretenție de autonomie a esteticului și devine instrument ideologic, de propagandă.

Metadiscursul anilor 1948-1964 despre acest subgen nu putea fi altfel decât paralizat într-o serie de clișee, la rândul lor, subordonate directivelor oficiale, de partid, dar acest status quo se modifică odată cu așa-numitul dezgheț ideologic (începând cu a doua jumătate a deceniului 7), când critica literară se întoarce către tematism și impresionism. În ciuda continuității de care se bucură romanul realistsocialist, care nu doar că nu dispare din peisajul literar românesc, ci cunoaște un adevărat reviriment în anii 1970-1980, receptarea sa, în condițiile noului val critic care încearcă să reînnoade legătura cu tradiția interbelică trunchiată de instaurarea totalitarismului, este relativ negativă sau pur și simplu absentă. Ce se întâmplă după 1990, odată cu liberalizarea societății și, în consecință, a criticii, cu posteritatea romanului realist socialist se leagă în primul rând de potențialul lui de obiect incriminator. Discursul anticomunist din România tranziției eșuează şi el să analizeze acest subgen ca unul literar - romanul realist-socialist reprezintă abia un alt instrument de propagandă al unui regim toxic și criminal. Violența acestui discurs reduce romanul scris între 1948 și 1964 la „schematism de subliteratură, simplitate vulgară și tâmpă”, la ,,antiintelctualism”, la „scriitură rudimentară [...] creată prin tehnici de manipulare”, la rezultatul unui ,plan minuțios întocmit de minți diabolice”, scris de „veleitari interbelici sau fripturiști” pentru „fanatici ai idealului egalitarist" (Negrici 2006, p. 22-24).

Această receptare bântuită permanent de spectrele datoriei și ideologiei politice nu a lăsat, în niciuna dintre perioadele în care romanul realist-socialist a fost fie

\footnotetext{
* Lucrarea de față este o variantă în limba română, revizuită și contrasă, a unui articol în curs de publicare.
} 
produs, fie discutat „la cald” de către critica literară, loc pentru analize neutre, care să privească acest subgen în dimensiunea lui de produs literar, de moment istoric în linia de evoluție a romanului românesc. Contribuții de dată extrem de recentă care vin din zona „,criticii de export” din România (titulatură omologată de Andrei Terian) au inițiat un proces de revizitare, cu un instrumentar metodologic cu proprietăți științifice (în speță, cercetări cantitative) a primelor decenii ale comunismului românesc și, în consecință, de reintegrare a romanului realist-socialist în traseul general al literaturii române, chiar dacă analize mai specializate pe acest corpus nu sunt încă disponibile (vezi Terian 2019). Astfel, literatura ideologică este pentru prima dată privită într-o lumină nouă, de la o oarecare distanță care are avantajul unei poziții de neutralitate. Lucrarea de față își propune să continue aceste inițiative și să contribuie la revizitarea romanului realist-socialist, implicând într-o măsură cât mai mică posibil prejudecățile setate de discursul anticomunist.

Metodologia acestei lucrări este tributară câş̧tigurilor din paradigma distantreading. Contribuțiile de referință pentru această nouă vârstă a criticii literare, care poate aspira, în sfârșit, la un tip de legitimare de care s-au bucurat până acum doar științele tari, rămân cele semnate de Franco Moretti și de Margaret Cohen, care omologhează cei mai uzați termeni din acest domeniu, distant reading, respectiv the great unread, urmate de specialiști care au dus și mai departe colaborarea dintre metodele informatice și cele hermeneutice precum Matthew L. Jockers, Katherine Bode, Martin Paul Eve, Andrew Piper, Ted Underwood. Urmând aceste contribuții, cercetarea mea împrumută atât instrumente, cât și un model de gândire al producției literare. Voi angaja un instrument computațional de stilometrie pentru a măsura afinităţile dintre scriitori, pentru a verifica dacă clișeul monocordismului romanului realist-socialist rezistă și într-o altfel de analiză, dacă romanele realist-socialiste se pot diferenția, stilistic, prin metode computaționale, de romanele care aparțin altor subgenuri (romane științifico-fantastice, polițiste, de aventuri, de copii, rurale etc). Analiza stilistică are rădăcini vechi, primele experimente analoge datează din secolul al XIX-lea, odată cu intuițiile lui Augustus de Morgan și s-au concretizat mai târziu în metode de analiză legitime de care se leagă numele lui George Zipf sau David R. Cox (Holmes, Kardos 2003). În prezent, stilistica computațională este un procedeu în primul rând de verificare a paternitătiii textului, prin stabilirea afinităților stilistice între texte diferite. Pentru analiza de topic modelling voi încerca, cu ajutorul unui program specializat venit din spațiul francez (TXM), să stabilesc cele mai frecvente cuvinte cu conținut semantic (excluzând aşadar cuvinte de legătură, articole, prepoziții, de pildă). Ca instrument de vizualizare a datelor obținute cu ajutorul acestor programe am ales Gephi.

În cazul romanului realist-socialist, provocările sunt cu atât mai interesante cu cât acesta reprezintă unul dintre rarele cazuri în care rețeta „,non-literară” precedă praxisul propriu-zis. În termeni stilistici, despre romanul realist-socialist s-a discutat puțin. Această reținere se datorează în speță prejudecății sau, dimpotrivă, directivelor ideologice: critica contemporană romanului realist-socialist nu căuta o validare estetică pentru simplul fapt că aceasta nu era pe lista de preocupări a 
partidului în ceea ce privea această literatură - pe care masele o puteau și pricepe, și învăța să o scrie (Dragomir 2003); critica anticomunistă vedea în romanul realistsocialist un subgen subliterar, care nu merita niciun fel de atenție. Eforturile de revizitare și de nuanțare care au avut loc în anii 1990 pe plaja studiilor internaționale (vezi Lahusen, Dobrenko 1997) au făcut referire, mai degrabă, la literatura socialistă interbelică, realismul stalinist a avut, în alte spații, și o vocație socialistă proliferată în artă. La noi, însă, astfel de cazuri au fost sporadice și fără ecou, iar literatura stalinistă a intrat pe scena literaturii române strict ca anexă ideologică. Este, astfel, lesne de înțeles violența cu care acest segment literar a fost respins și condamnat după liberalizare. Înainte de a verifica computațional coordonatele de stil și subiect, acestea ne sunt date, fără rezerve, de comentatorii săi. Din punct de vedere stilistic, ,,comandamentul principal al literaturii de propagandă a fost accesibilitatea. Expresia trebuia să fie simplă, uşor de recunoscut, proza se cuvenea să respecte o rețetă pedagogică, leșinată" (Negrici 2006, p. 22). Din punct de vedere al rețelelor de afecte, acestea trebuiau să mizeze pe „ură, sentimentalism și emoționalitate" (ibidem, p. 20). Din punct de vedere tematic, de la romanul realist-socialist se pretindea „o reprezentare veridică, istoric concretă a realităţii în dezvoltarea ei revoluționară" (Aucouturier 2001, p. 6). Un experiment computaţional aplicat pe un corpus de roman realist-socialist poate fie să confirme aceste clișee vehiculate, fie să le infirme - o ipoteză destul de improbabilă - prin descoperirea unei diversităţi tematice (cu ajutorul topic modellingului) sau stilistice (cu ajutorul analizei stilometrice), obscurizată până acum de lentila tradițională tributară prejudecăților politice. Poate cea mai realistă așteptare este cea a confirmării, în linii mari, a rețetei, dar asta nu exclude, cred, posibilitatea deschiderii unui dialog care să nuanțeze discursul anticomunist şi care să încerce să privească romanul realist-socialist de la o distanță pe care cele mai consistente și vizibile studii dedicate acestuia nu o au. Următorul segment al acestei lucrări va încerca să împlinească un astfel de demers.

În primul rând, câteva precizări tehnice se impun. Selecţia corpusului a urmat rațiuni dintre cele mai simple. În primul rând, număr mic de romane este un rezultat direct al muncii individuale în studiile computaționale, care, în general, pledează pentru cercetarea colaborativă, pentru formarea unor echipe de lucru care să realizeze constituirea și procesarea corpusului și colectarea de date în vederea dezvoltării unui proces mai eficient și mai riguros verificat. În interiorul acestui corpus se găsesc mai multe subgenuri, tranșarea lor, însă, este în două categorii: romane realist-socialiste, conforme cu prescripțiile literaturii sovietice impuse de Partidul Comunist, care, mimând producția din teren, sunt majoritare și în interiorul acestui corpus, și romane care aparțin altor subgenuri: de copii și tineret, de aventuri, științifico-fantastic, istoric, rural, social - adică subgenurile predilecte și care sunt relativ bine reprezentate în perioadă. În interiorul acestor două categorii, am încercat să cuprind atât romane recunoscute, canonice sau care au avut cel puțin un succes mare la data publicării (semnate de autori ca Eugen Barbu, Zaharia Stancu, Constantin Chiriță sau 
Petru Dumitriu) şi proze aparţinând unor autori care au rămas în umbră. Prelucrarea corpusului a reprezentat un proces la fel de anevoios. De vreme ce majoritatea romanelor se află încă sub protecția legii copy right-ului, digitizarea și prelucrarea lor pentru această analiză în forma necesară programelor utilizate (forma finală a romanului este un document curat, în format .txt) fac și ele parte din laboratorul acestei lucrări, fiind un demers individual ale cărui produse au fost utilizate strict în scopurile de cercetare. Orice erori care vor duce la rezultate doar parțiale, așadar, îmi aparțin. În câmpul Digital Humanities, chiar și un demers individual va pleda pentru o nouă formă - cooperativă, colaborativă - de a face critică literară, semnalând neajunsurile demersurilor făcute la o singură pereche de mâini.

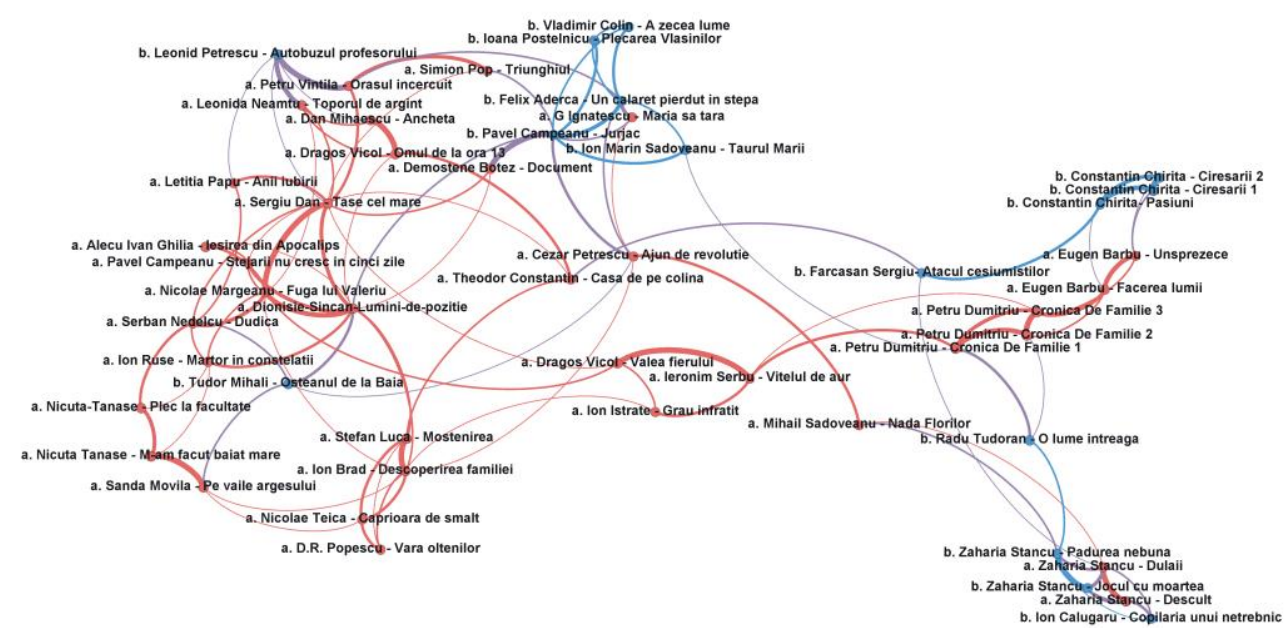

Figura 1. Rețea realizată cu un corpus de 50 de romane din perioada 1948-1964, dintre care 35 realist-socialiste (roșu) și 15 aparținând altor subgenuri (albastru)realist-socialiste (roșu) și 15 aparținând altor subgenuri (albastru)

Conform DCRR, romanul realist-socialist ocupă, ca subgen, peste $70 \%$ din producția totală de roman din perioada 1948-1964. Sporadice și puține, subgenuri precum romanul social, de familie, de aventuri, științifico-fantastic sau romanul rural reușesc totuși să constituie un filon, pe de o parte, constant în prezență, pe de altă parte, capabil să dea opere semnificative și recunoscute. În corpusul utilizat în lucrarea de față, se regăsesc, așa cum am precizat deja, mostre din fiecare subgen. Imaginile rezultate au la bază un demers hibrid, care îmbină algoritmii automați cu un demers de interpretare. În primul rând, am întreprins o analiză stilometrică a cărei miză a fost localizarea romanului realist-socialist într-un corpus mixt de subgenuri. Prima curiozitate s-a legat de afinitatea stilistică a romanului realist-socialist, iar rezultatul a fost, în mare, coerent cu aşteptările. Figura 1 reprezintă redarea grafică a unui demers computaţional de analiză a afinităţilor stilistice între textele 
utilizate, realizată cu Stylo (Eder et alii 2016). Corpusul utilizat cuprinde un număr de 50 de romane, dintre care 35 realist-socialiste (conform unei judecăţi duble: o dată în funcție de DCRR, o dată în funcție de consensul critic, acolo unde romanele s-au bucurat de receptare în epocă și mai târziu), respectiv 15 care aparțin altor subgenuri pe care le-am precizat deja. Romanele realist-socialiste au fost marcate cu formula ,a. nume autor - titlu roman”, iar restul, cu formula „b. nume autor titlu roman". Prima categorie poartă culoarea roșie, a doua, culoarea albastră.

Așa cum era de așteptat, cele mai multe dintre romanele realist-socialiste prezintă afinități și formează, în consecință, clustere relativ omogene. În partea stângă se formează principalul bastion al romanului realist-socialist, care are, așadar, și în materie de stil, asemănări puternice. Cu toate acestea, peisajul conține și o umbră de diversitate. $\mathrm{Nu}$ doar că unele romane din categoria „b.” ajung în formațiunea predilectă „a.” (chiar dacă autorii care le semnează nu se regăsesc și în cealaltă categorie, deci nu reprezintă o afinitate legată de auctorialitate), dar și romanele de categorie „a." tind să formeze propriile grupări oarecum independente unele de altele. Astfel, primul cluster (stânga, sus) tinde să se apropie mai degrabă de romanul fără rețetă. Petru Vintilă, Dan Mihăescu, Dragoș Vicol, Demostene Botez, Simion Pop ș.a. semnează romane minore, care, în principiu, corespund rețetei realist-socialiste. În praxis, apropierea lor de romanele unui Vladimir Colin, Leonid Petrescu sau Felix Aderca, de pildă, se poate traduce prin uzul unor mărci stilistice specifice discursului romanului de aventuri. Următorul cluster care începe cu romanul Letiției Papu - care înregistrează și el o legătură cu romanul pentru copii și tineret al lui Leonid Petrescu - continuă cu o suită de romane dintre care abia cele care se despart relativ, în capătul rețelei, sunt semnate de nume cunoscute: Sanda Movilă și D. R. Popescu, ambele romane rurale care adresează subiecte legate de exploatarea claselor muncitoare și de procesul colectivizării. Plasarea în rețea a romanului lui D. R. Popescu nu este întâmplătoare - despre Vara oltenilor, receptarea critică a avut cuvinte de laudă la adresa stilului și esteticii, consensul fiind că talentul de prozator al lui D. R. Popescu a reușit, chiar și în chingile strâmte ale rețetei realist-socialiste, să dea un roman lizibil și dincolo de ideologia propusă. În centrul rețelei se plasează autori minori (mai bine legați între ei și tributari, se pare, acelorași directive stilistice) și (cvasi)canonicii Cezar Petrescu și Mihail Sadoveanu, ambii într-o zonă de intersecție. Deși romane realist-socialiste, Ajun de revoluție și Nada florilor se leagă stilistic de alți (cvasi)canonici: Felix Aderca și Zaharia Stancu. Un alt cluster important este format din canonicii Eugen Barbu și Petru Dumitriu, care prezintă și ei afinităţi cu Radu Tudoran și Constantin Chiriţă, alţi autori recunoscuţi în epocă și care dau romane bine receptate şi citite până în prezent. În fine, în partea dreaptă, jos, se află cel mai bine individualizat autor, Zaharia Stancu, a cărui scriitură depășește rigorile subgenurilor. Romanele „după rețetă” și romanele sociale ale lui Zaharia Stancu (poate singurul caz relevant în care realism-socialismului i s-ar putea „egala” proletcultismul în România) 
sunt citite de către computer ca scriitură comună. Curioasă este plasarea romanului lui Ion Călugăru în proximitatea acestora. Copilăria unui netrebnic reprezintă, însă, un caz particular. Scris mai devreme, dar publicat în 1954, romanul lui Ion Călugăru nu face parte din lista romanelor realist-socialiste redactate după directivele oficiale de partid. $\mathrm{Cu}$ toate acestea, putem argumenta pentru un alt caz asemănător lui Zaharia Stancu, care se supune mai degrabă perceptelor proletcultiste decât rețetei realist-socialiste. Discursul românesc anticomunist a pus adeseori semn de egalitate între realism-socialist și proletcultism sau le-au citit, cel puțin, într-o cheie evolutivă. Realism-socialismul a fost, în viziunea multor comentatori, o continuare a principiilor literaturii proletcultiste, literatură care, în spaţiul românesc, a fost aproape absentă (vezi Cordoș 2002). Afinitatea dintre cei doi autori, pe de o parte, și distanța dintre romanele realist-socialiste ale lui Zaharia Stancu față de romanele realist-socialiste „clasice” din epocă, pe de altă parte, conduc la nuanțarea acestei interpretări care vizează legătura dintre literatura proletcultistă și realismul-socialist.

Dinamica prezentată cu ajutorul lui Stylo și redată în rețeaua de mai sus conduce, aşadar, la câteva rezultate, chiar dacă mai degrabă experimentale. În primul rând, ea nu destabilizează prea mult consensul critic - romanul realist-socialist tinde să se despartă de restul romanelor și să prezinte afinități stilistice. În al doilea rând, se menține ierarhia canonică - romanele bine receptate sunt și romane care se așază mai degrabă împreună și la distanță de romanele minore. Cu toate acestea, rețeaua de mai sus nu arată întru totul ca imaginea construită despre romanul scris între 1948 și 1964. Firește, corpusul de romane este mic și mostrele alese pot fi mai mult sau mai puțin relevante, cred, însă, că asta nu le face mai puțin grăitoare. Distanțele și apropierile pot fi traduse prin relativizări ale judecăţilor de valoare. Această „subliteratură”, cum o numesc reprezentanții corului anticomunist post-decembrist, are, totuși, un comportament literar, care recunoaște vârfurile, estetica fiecărui autor și o anumită dinamică în interiorul unui câmp - deși mutilat de ideologie - totuși, literar. Această reprezentare spune puține în termeni de valoare, dar o recuperare valorică a realismului socialist nu era în chestiune. Ceea ce poate comunica această analiză se leagă de o oarecare demnitate a traseului romanului românesc care, deși este parțial înfrânt de ideologie, își păstrează, la nivel macroeconomic, un anumit habitus important în economia dezvoltării ulterioare dezghețului ideologic și, mai apoi, a liberalizării pieței de carte.

Al doilea tip de analiză care are mize oarecum coerente este realizată în TXM (Salem 1994; Magué, Pincemin 2010). Corpusul utilizat a rămas același. Am urmărit felul în care subgenul și/sau tema romanelor pot fi extrase prin metode computaționale (care presupun cantitatea minimă de interpretare din partea cercetătorului). Principalul răspuns pe care 1 -am căutat s-a legat de posibilitatea de a stabili apartenența unui roman la subgenul realist-socialist prin repetarea unor anumite tendințe tematice. 


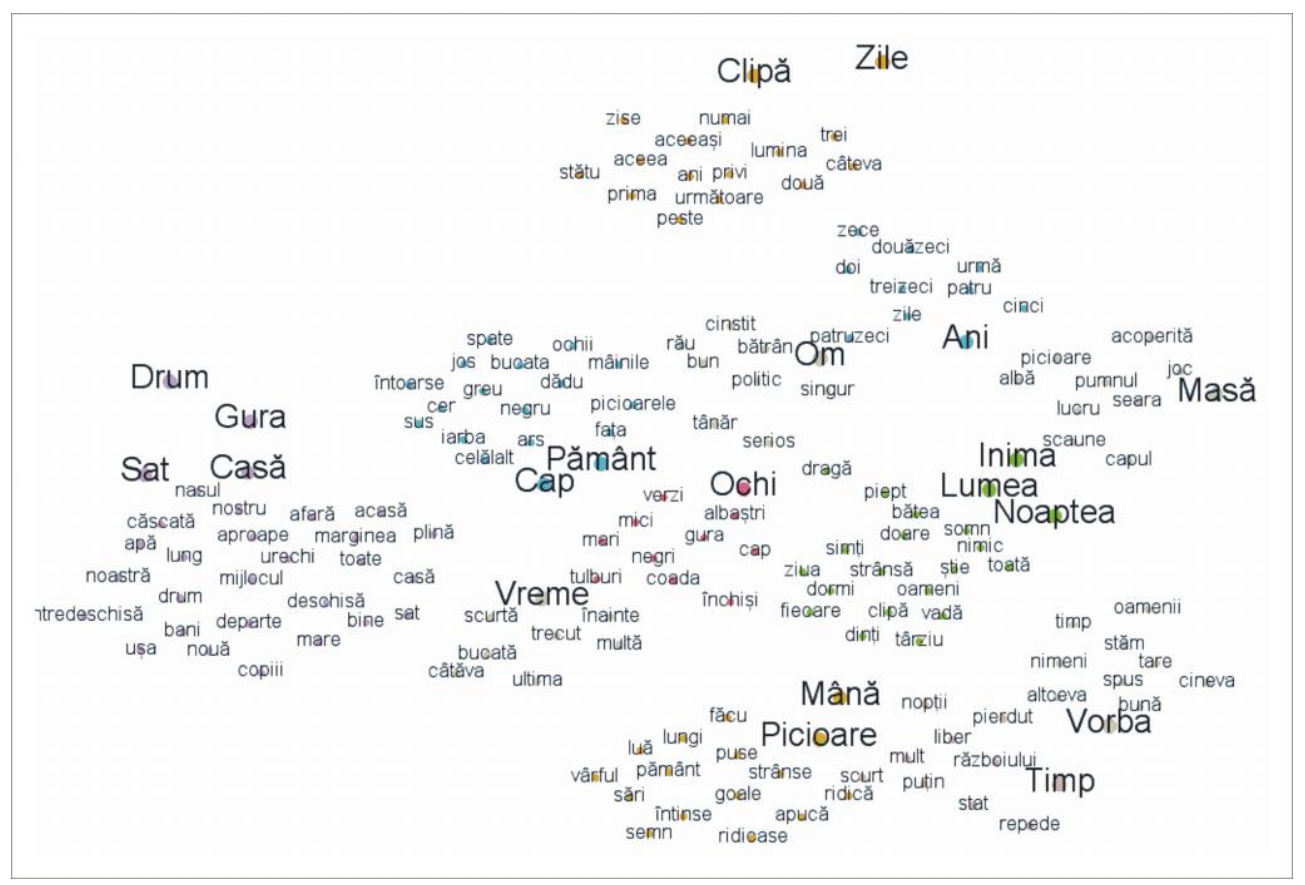

Figura 2. Rețeaua cuvintelor frecvente și a co-ocurențelor eșantionului realist-socialist

Rețeaua de mai sus conține cele mai frecvente cuvinte de conținut din cele 35 de romane realist-socialiste utilizate drept mostră de lucru. Acestea sunt cuvintele mai mari și care formează clustere de sine stătătoare cu primele 10 cuvinte de conținut care reprezintă co-ocurențele fiecăruia. Suprapunerea unor cuvinte în cazul co-ocurențelor a creat un soi de echivoc. Astfel, cuvintele frecvente au format clustere acolo unde co-ocurențele s-au suprapus într-un număr semnificativ. În cele mai multe cazuri, faptul s-a datorat unor expresii de tipul „cu capul/ochii în pământ”.

Din analiza cuvintelor de conținut găsite drept cele mai frecvente, putem desprinde trei mari teme: corporalitatea formată din cuvinte (gură, cap, ochi, mână, picioare) ale căror co-frecvențe sunt, în speță, adjective referitoare la trăsături fizice (,gură mare”, „întredeschisă”, ochi negri, verzi, albaștri etc); temporalitatea (clipă, zile, ani, noapte, timp, vreme); condiția umană (om, inimă, lume, vorba, pământ, sat, casă, drum). Rețeta romanului realist-socialist se articula în jurul temelor vieții sociale. Cele mai frecvente cuvinte enumerate mai sus sunt, așadar, doar parțial o surpriză. Fiind vorbe de teme mai degrabă generice, ele se pot plia pe directivele ideologice, dar pot totodată susține argumentul unui realism-socialist cu o structură complexă într-o mai mare măsură decât s-ar fi putut crede, a cărei infrastructură morfologică vine ca o continuare firească și naturală a literaturii de până la 1948, care este, înainte de toate, încă preocupată de reacțiile umane la evenimentele istorice sau personale. 
Pentru ca aceste date să fie mai relevante, se impune și o comparație cu segmentul de corpus care cuprinde alte subgenuri.

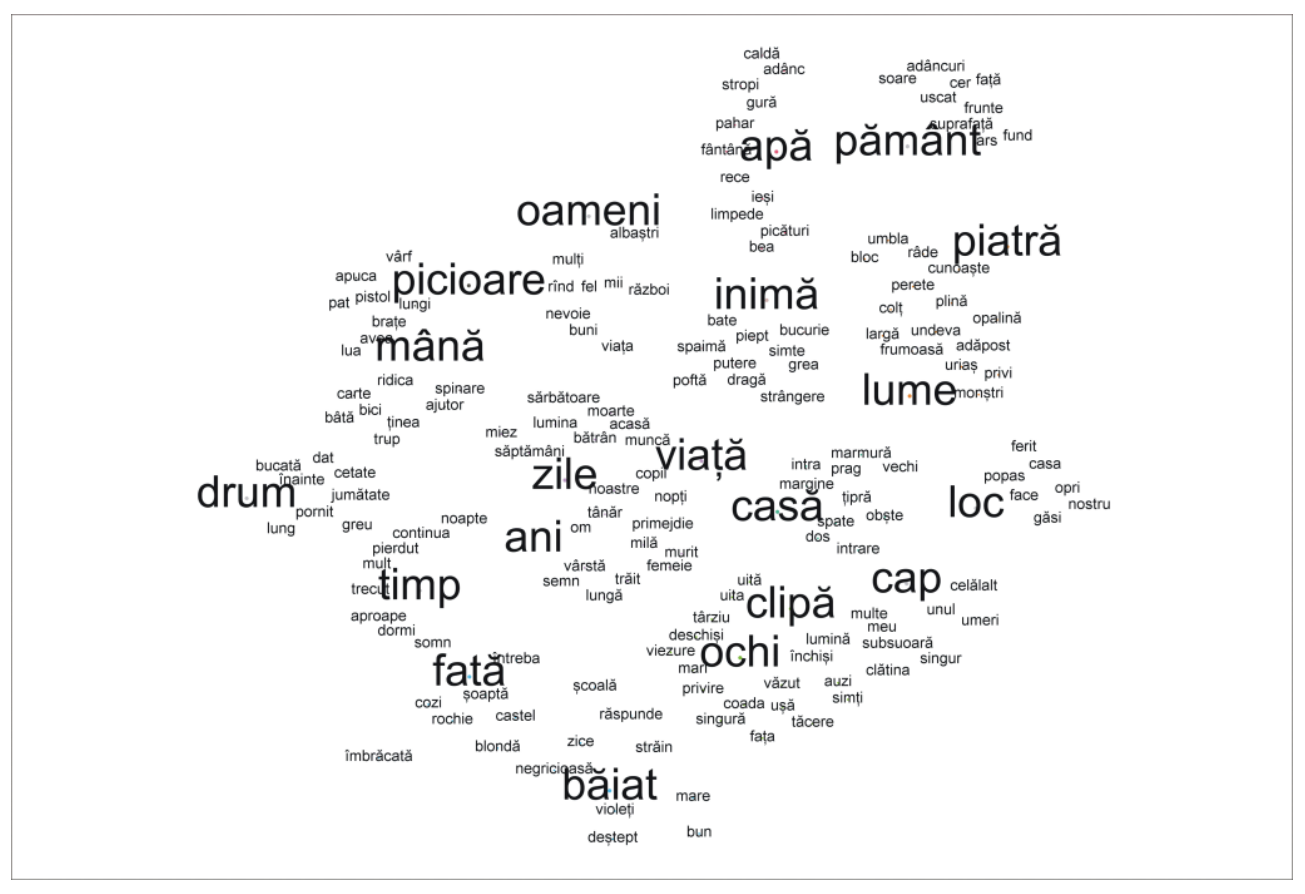

Figura 3. Rețeaua cuvintelor frecvente și a co-ocurențelor eșantionului aparţinând altor subgenuri decât realism-socialist.

Figura de mai sus funcționează după aceleași principii. Cele mai frecvente cuvinte conduc, în cazul romanelor de aventură, sociale etc., la teme asemănătoare: corporalitate (ochi, cap, picioare, mână), natură (apă, pământ, piatră, loc, drum), temporalitate (timp, zile, ani, clipă, timp) și condiție umană (oameni, fată, băiat, inimă, lume, viaţă). Prezența mai multor cuvinte din câmpul semantic al naturii se explică prin faptul că majoritatea romanelor care nu erau realist-socialiste erau romane de aventură sau pentru copii și tineret (de unde și prezența foarte mare a termenilor fată și băiat). Romanul realist-socialist nu pare să fie mai preocupat de corporalitate și de zona domestică, cea mai simplistă și reducționistă concluzie comparativă fiind aceea că, dacă romanul realist-socialist se petrecea mai degrabă înăuntru, în medii private sau publice închise și se baza pe relaționarea între personaje și atenţia asupra acestora și pe atenția asupra expresiilor faciale și a limbajului corporal, romanul „„ără rețetă” performa acest tip de escapism al mediilor naturale, al tramelor copilăriei și adolescenței, al universurilor compensative fantastice sau izolate, la distanță de sfera socială, politică. Diferențele și mai mari apar atunci când ne uităm la co-ocurențele care însoțesc aceste cuvinte de conținut. În jurul 
părților corpului se acumulează adjective referitoare la dimensiune și culoare (ochi mari, negri, verzi, de pildă) sau referitoare la expresie (coada din expresia „cu coada ochiului”, „gura întredeschisă”, „gura la urechi” etc.). Separațiile interesante apar acolo unde sunt utilizate verbele. Să luăm cazul substantivului „mână”, de pildă. În romanele realist-socialiste, cele mai multe coocurențe sunt date de verbele „,̂ntinse”, ,puse”, „luă”, „ridică”, „,ădu”, „,ăcu”, ,apucă”, „strânse”. În cazul romanelor din alte subgenuri, cele mai frecvente cuvinte sunt verbele „a ține”, ,a avea”, ,a apuca”, „, lua”, dar și substantivele „pistol”, „,bici”, „piatră”, „carte”, „bâtă”. Astfel, dacă co-ocurențele din primul caz trădează un volum mare de episoade în care este descrisă o conduită domestică sau socială a personajelor, în al doilea caz ele semnalează, iarăși, trame de acțiune. În cazul substantivului „picioare", co-ocurențele se suprapun în mare parte, cu excepția unor cuvinte ce fac parte din expresii. Curioasă este frecvența co-ocurenței „spinare”, care provine, cel mai probabil, din expresia „cu picioarele în spinare”, o altă marcă a unui discurs de roman de aventuri. Diferența de subgen este, așadar, vizibilă și la un astfel de nivel, acest segment de analiză constituind totodată și un argument pentru metodologia, nu doar pentru subiectul - lucrării de față: există șanse ca, prin analize complexe și mai bine documentate și pregătite decât cea de față, instrumentele de topic modelling și chiar și cele stilometrice să poate recunoaște subgenurile romanelor.

În ceea ce privește temporalitatea, co-ocurențele din jurul substantivelor care desemnează timpul trădează fie un timp istoricizant, al povestirii, în cazul romanului realist-socialist, care acumulează co-ocurențe precum perioade destul de mari de timp (doi, cinci, douăzeci, treizeci de ani etc.), fie un ritm alert, al acțiunii în cazul romanului de aventură, copii etc. (miez, primejdie, semn, lumină, trăit, sărbătoare etc.). Interesantă este și situația substantivului ,,inimă” - o apariție, în sine, destul de curioasă în economia subgenurilor vizate, dintre care nici măcar un roman nu este de dragoste sau sentimental. În cazul romanului realist socialist, co-ocurențele vizează sentimente mai degrabă negative sau stări de tensiune (,inima strânsă”, care se traduce printr-un sentiment de frică, verbele „bătea”, ,doare”, substantivele „piept”, „dinți”, din expresiile ,să sară din piept”, care traduce un sentiment de emoție atât pozitivă, cât și negativă, de bucurie sau furie, și ,a lua inima în dinți”, care traduce o luare de poziție, prin curaj, dar silit, nu eroic). În cazul celorlalte romane, se adaugă și co-ocurențe precum „bucurie” și „poftă” sau „putere”, care traduc, iarăși, atribute ale unor narațiuni de aventuri, de acțiune, cu calități idilice, chiar romantice (eroism). În final, în romanele de aventuri și pentru tineret, această analiză traduce și latura pedagogică, tributară un stereotipii de gen încă active în epocă. În jurul substantivului „fată” se concentrează cuvinte legate de îmbrăcăminte sau păr (,,blondă”, „,cozi”, ,îmbrăcată”, ,,rochie”, „violeți” - probabil dintr-o sintagmă legată tot de un obiect vestimentar) și verbe precum ,a întreba”, ,a şopti”, în timp ce, în jurul substantivului „băiat” se remarcă verbe precum ,a zice”, „a răspunde”, adjective precum „bun”, „deștept”, „mare”, substantivele „școală”, „mână”, „ochi”. Lista este aproape auto-expozitivă. Fetele erau ființele pasive, decorative, băieții, actanții principali și dirijorii narațiunii. 
Care este, aşadar, profilul romanului realist-socialist atunci când i se aplică un asemenea tratament? Merită să fie recuperat ca secvență a literaturii române într-o privire care-i urmărește evoluția istorică? Fără a avea vreo pretenție de a răspunde într-un mod relevant la întrebarea referitoare la calitatea literaturii realist-socialiste sau la problemele ce țin de sfera eticii, analiza mea a vrut să argumenteze în favoarea unei reincluderi a romanului din perioada 1948-1964 în conversațiile despre literatura română. Imaginea stilistică și tematică a romanului realist-socialist este coerentă cu dinamica câmpului literar și continuă să abordeze teme care erau de interes şi în perioada interbelică sau mai devreme. Am privit romanul realistsocialist de la o dublă distanță: una istorică, încercând o abordare cât mai puțin alterată de prejudecățile și clișeele discursului anticomunist din România de după anii 1990, una metodologică, uzând de avantajele distant reading-ului, în speranța că datele de față vor fi un instrument util în abordări ulterioare ale producției de roman românesc din primele două decenii sub comunism.

\section{ABREVIERI BIBLIOGRAFICE. SIGLE}

Aucouturier 2001 = Michel Aucouturier, Michel Acouturier, Realismul socialist . Traducere de Lucia Flonta, Cluj-Napoca, Dacia, 2001.

Cordoş 2002 = Sanda Cordoş, Literatura între revoluţie şi reacţiune. Problema crizei în literatura română şi rusă a secolului XX, ediţia a II-a, Cluj-Napoca, Editura Biblioteca Apostrof, 2002.

DCRR = Dicționarul cronologic al romanului românesc de la origini până la 1989, București, Editura Academiei Române, 2004.

Dragomir 2003 = Lucia Dragomir, L'implantation du réalisme socialiste en Roumanie, în „Sociétés \& Représentations", 2003, 15, nr. 1, p. 307-324.

Eder et alii 2016 = Maciej Eder, Jan Rybicki, Mike Kestemont, Stylometry with R: A Package for Computational Text Analysis, în „The R Journal”, 2016, vol. 8, nr. 1, p. 107-121.

Goldiș 2011 = Alex Goldiș, Critica în tranșee. De la realismul socialist la autonomia esteticului, București, Editura Cartea Românească, 2011.

Holmes, Kardos 2003 = David Holmes, Judit Kardos, Who Was the Author? An Introduction to Stylometry, în „CHANCE”, 2003, vol. 16, nr. 2, p. 5-8.

Lahusen, Dobrenko 1997 = Thomas Lahusen, Evgeny Dobrenko (eds.), Socialist Realism without Shores, Durham, Duke University Press, 1997.

Magué, Pincemin $2010=$ Heiden S. Magué, J. P. Pincemin, TXM: une plateforme logicielle opensource pour la textométrie - conception et développement, în S. Bolasco, I. Chiari and L. Giuliano (eds.), „Proceedings of 10th International Conference on the Statistical Analysis of Textual Data - JADT 2010", Roma, Edizioni Universitarie di Lettere Economia Diritto, 2010, p. $1021-1032$.

Negrici 2006 = Eugen Negrici, Literatura română sub comunism. Proza, București, Editura Fundației PRO, 2006.

Salem 1994 = Lebart L. Salem, Statistique Textuelle, Paris, Dunod, 1994.

Selejan 2007 = Ana Selejan, Literatura în totalitarism 1949-1951. Intemeietori și capodopere, București, Editura Cartea Românească, 2007.

Terian $2019=$ Andrei Terian, Big numbers. A Quantitative Analysis of the Development of the Novel in Romania, în „Transylvanian Review”, XXVIII, 2019, supl. nr. 1, p. 56-71. 


\section{THE SOCIALIST-REALIST NOVEL IN ROMANIA. A STYLOMETRIC APPROACH (Abstract)}

After 1990, the predominant anti-Communist cultural discourse instituted a series of clichés regarding the literary production of the Communist period. One of the most powerful discursive commonplaces relates to the thematic and formal uniformity of the socialist-realist novel written between 1948 and 1964. Judged almost unanimously as a type of novel devoid of aesthetic value, the socialist-realist novel was interpreted strictly as a form of ideologization and imposition of statemandated doctrine. However, how rigid is this subgenre? How does the recipe truly develop in the literary novelistic praxis? My paper proposes a two-fold analysis of the novel written in Romania between 1948 and 1964 that will account for both the style and the thematic range of the socialistrealist subgenre. With the help of computational instruments, I will attempt to generate a stylometric analysis (computational stylistics) in order to identify patterns and affinities between authors and subgenres. At the same time, I will also create a topic model of the aforementioned literary production in order to illustrate the thematic spectrum of these novels, alongside their prevalent subjects and their relationship with the directives given by the Communist party. My study will try, through these digital instruments, to lay bare aspects of this literary subgenre that were ignored in the contemporary critical and historiographical discourse, while also proposing a reassessment of the literary field of the so-called "obsessive decade".

Cuvinte-cheie: roman realist-socialist, roman românesc, stilometrie, modelare tematică, distant reading.

Keywords: socialist-realist novel, Romanian novel, stylometry, topic modelling, distant reading.

Universitatea Babeș-Bolyai Facultatea de Litere

Cluj-Napoca, str. Horea, 31

daiana.gardan@lett.ubbcluj.ro 